\title{
Discovery of Sabellaria spinulosa reefs in an intensively fished area of the Dutch Continental Shelf, North Sea
}

\author{
Karin J. van der Reijden ${ }^{\mathrm{a}, *}$, Leo Koop ${ }^{\mathrm{b}}$, Sarah O'Flynn ${ }^{\mathrm{c}}$, Silvia Garcia ${ }^{\mathrm{d}}$, Oscar Bos ${ }^{\mathrm{e}}$, \\ Christiaan van Sluis ${ }^{\mathrm{f}}$, David J. Maaholm ${ }^{\mathrm{d}}$, Peter M.J. Herman ${ }^{\mathrm{g}, \mathrm{h}}$, Dick G. Simons ${ }^{\mathrm{b}}$, Han Olff ${ }^{\mathrm{a}}$, \\ Tom Ysebaert $^{\mathrm{c}, \mathrm{e}}$, Mirjam Snellen ${ }^{\mathrm{b}}$, Laura L. Govers ${ }^{\mathrm{a}, \mathrm{i}}$, Adriaan D. Rijnsdorp ${ }^{\mathrm{e}, \mathrm{j}}$, Ricardo Aguilar ${ }^{\mathrm{d}}$ \\ ${ }^{a}$ Conservation Ecology Group, Groningen Institute for Evolutionary Life Sciences, University of Groningen, P.O. Box 11103, 9700 CC Groningen, the Netherlands \\ ${ }^{\mathrm{b}}$ Acoustics Group, Delft University of Technology, 2629 HS Delft, the Netherlands \\ ${ }^{\mathrm{c}}$ NIOZ Royal Netherlands Institute for Sea Research, Department of Estuarine \& Delta Systems, Utrecht University, P.O. Box 140, 4400 AC Yerseke, the Netherlands \\ ' OCEANA Europe, Gran Via 59, 28013 Madrid, Spain \\ e Wageningen Marine Research, P.O. Box 68, 1970 AB IJmuiden, the Netherlands \\ ${ }^{\mathrm{f}}$ The North Sea Foundation, P.O. Box 1578, 3500 BN Utrecht, the Netherlands \\ ${ }^{\mathrm{g}}$ DELTARES, P.O. Box 177, $2600 \mathrm{MH}$ Delft, the Netherlands \\ ${ }^{\mathrm{h}}$ Delft University of Technology, Hydraulic Engineering, 2629 HS Delft, the Netherlands \\ ${ }^{\mathrm{i}}$ NIOZ Royal Netherlands Institute for Sea Research, Department of Coastal Systems, Utrecht University, PO Box 59, 1790 AB Den Burg, the Netherlands \\ ${ }^{\mathrm{j}}$ Aquaculture and Fisheries Group, Wageningen University, P.O. Box 338, 6700 AH Wageningen, the Netherlands
}

A R T I C L E I N F O

\section{Keywords:}

Biogenic Reef

Brown Bank

Ecosystem Engineer

Sabellaria spinulosa

North Sea

\begin{abstract}
A B S T R A C T
The tube-building polychaete Sabellaria spinulosa (Ross worm) can form conspicuous biogenic reefs that stabilize the seabed and increase biodiversity by providing a habitat for a multitude of other species. These reefs, however, are assumed to be vulnerable to human-induced physical disturbances of the seabed. In the Greater North Sea, $S$. spinulosa reefs are recognized to be under threat and worthy of protection. In August 2017, three $S$. spinulosa reefs with a minimum extent of $1016 \mathrm{~m}^{2}$ were discovered in the Dutch Brown Bank area. This area comprises a large-scale sandbank and adjacent troughs. The reefs were found within the sandbank troughs, which have proven to be subject to high demersal fishing intensities (fished $>5$ times a year). Detailed bathymetry measurements showed that $S$. spinulosa reefs were mainly located within valleys of smaller-scaled sand waves, which have a perpendicular orientation compared to the large-scale sandbank structure of the Brown Bank. We hypothesize that the valleys in between sand waves offer suitable substrate for settlement and refuge from abrasion by fishing activities, enabling the $S$. spinulosa reefs to persist despite high fishing intensities. ROV footage of the reefs showed higher estimates of species abundances on the reefs compared with adjacent habitats, with some species present that are typical for hard substrate (rock gunnel, Pholis gunnellus; edible crab, Cancer pagurus; and velvet swimming crab, Necora puber). The information presented could be used for drafting management policies to protect these reefs, as Contracting Parties of the OSPAR Convention are committed to take measures and protect biodiversity.
\end{abstract}

\section{Introduction}

Biogenic reefs are formed by ecosystem engineers, and are known to promote biodiversity of otherwise soft sediment bottoms by increasing habitat complexity and adjusting prevailing environmental conditions (Connell, 1978; Jones et al., 1994). The best known biogenic reefs are built by corals, but in temperate waters multiple species with similar reef-building properties can be found. For instance, some sponges are known to increase habitat complexity (Ryer et al., 2004), while oysters, mussels, and sand mason worms form beds that act as biogenic reefs (Lenihan, 1999; Rabaut et al., 2009; van der Zee et al., 2012). Habitat complexity provides refuge possibilities and suitable substrate for

\footnotetext{
* Corresponding author.

E-mail addresses: k.j.van.der.reijden@rug.nl (K.J. van der Reijden), 1.koop@tudelft.nl (L. Koop), sarah.oflynn@nioz.nl (S. O'Flynn), sgarcia@oceana.org (S. Garcia), oscar.bos@wur.nl (O. Bos), c.vansluis@noordzee.nl (C. van Sluis), peter.herman@deltares.nl (P.M.J. Herman),

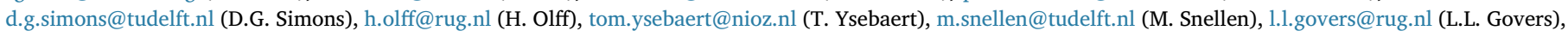
adriaan.rijnsdorp@wur.nl (A.D. Rijnsdorp), raguilar@oceana.org (R. Aguilar).
} 
settlement (Gratwicke and Speight, 2005) as well as food provisioning for multiple, higher-trophic species (van der Zee et al., 2016). Biogenic reefs also stabilize sediments and reduce current and wave speeds (Ferrario et al., 2014; Lenihan, 1999), enabling the settlement of species requiring conditions of low hydrodynamic stress (Donadi et al., 2013). However, biogenic reefs are disappearing on a worldwide-scale due to anthropogenic pressures (Airoldi and Beck, 2007; HoeghGuldberg et al., 2008). Where coral reefs are mainly affected by global warming and acidification (Hoegh-Guldberg et al., 2008), sediment disturbing practices, such as demersal fisheries, are thought to have a high negative impact on temperate biogenic reefs (Bordehore et al., 2003; Hiddink et al., 2017).

The sedentary polychaete Sabellaria spinulosa is capable of forming such biogenic reefs, by creating aggregations of thousands of individual tubes from sand particles (Hendrick and Foster-Smith, 2006; Lisco et al., 2017). The polychaete has a wide distribution, with recordings in the Atlantic, the North Sea, the Mediterranean Sea and the English Channel (Gravina et al., 2018; Pearce, 2014; The Marine Life Information Network (MarLIN), n.d; The National Biodiversity Network (NBN), n.d). However, in most of its geographical range $S$. spinulosa is encountered as low numbers of individual worms encrusting available substrate, shells, and kelp holdfasts (Gibb et al., 2014; Hendrick and Foster-Smith, 2006; OSPAR Commission, 2013). The occasions in which S. spinulosa acts as an ecosystem engineer, by the e formation of biogenic reefs that are significantly elevated from the seabed, is thought to be rare, with the majority of the reefs established near the British coast (Gibb et al., 2014; OSPAR Commission, 2013; The Marine Life Information Network (MarLIN), n.d; The National Biodiversity Network (NBN), n.d). The areas around the North Norfolk coast and the Wash are particularly important for S. spinulosa establishment (Gibb et al., 2014). Reefs are less well known from elsewhere in the North Sea. Extensive, intertidal reefs have been present in the German Wadden Sea, but they have been completely lost (OSPAR Commission, 2013; 2010; Reise, 1982). On the Dutch Continental Shelf, solitary observations have been made during dredge sampling (Witbaard et al., 2013), diving expeditions (Stichting Duik de Noordzee Schoon, Bureau Waardenburg BV), and scientific ROV surveys (OCEANA North Sea Expedition 2016). Recordings of extensive $S$. spinulosa reefs, however, could not be found in either international or national databases (Marine Information and Data Centre, n.d $\mathrm{d}^{1}$; Ocean Biogeographic Information System (OBIS), n.d; The National Biodiversity Network (NBN), n.d). Moreover, after consultation with multiple Dutch North Sea scientists, researchers, policy makers and environmental agencies, we conclude that, currently, no $S$. spinulosa reefs are known on the Dutch Continental Shelf.

Based primarily on the reported decline of $S$. spinulosa reefs in the German Wadden Sea (OSPAR Commission, 2013 and references therein), the Convention for the Protection of the Marine Environment of the North-East Atlantic (OSPAR convention) has recognized that $S$. spinulosa reefs are threatened and in decline in the Greater North Sea (OSPAR Commission, 2013). The largest threat to $S$. spinulosa reefs is thought to be abrasion by physical disturbance (OSPAR Commission, 2013). Sand extraction and demersal fisheries impose a particularly high risk, as these activities damage the tubes and remove (parts of the) reef (Gibb et al., 2014). Multiple studies conclude that fisheries are the most likely explanation of reef destruction (Collins, 2003, cited from OSPAR Commission, 2013; Reise and Schubert, 1987). Other studies show clear trawl scars and other signs of trawling damage in S. spinulosa reefs (Limpenny et al., 2010; Pearce, 2014).

In this study, however, we report on the discovery of three separate S. spinulosa reefs in an intensively fished area on the Dutch Continental Shelf. In August 2017, the reefs were unexpectedly observed in the

\footnotetext{
${ }^{1}$ Dutch National database for governmental benthos surveys for the Marine Strategy Framework Directive, as described in (Dutch Ministry of Infrastructure and the Environment, 2014).
}

Brown Bank area during an expedition of OCEANA. This expedition aimed to strengthen the networks of Marine Protected Areas in the North Sea, by documenting habitats and species in 16 areas. Acoustic and videographic data and sediment samples were collected serendipitously within and around these reefs. In addition, surrounding patterns of demersal fishing activity were determined from Vessel Monitoring System (VMS) data.

\section{Materials and methods}

\subsection{Study area}

In August 2017, the research vessel 'Neptune' was used to investigate benthic habitats and communities in the Brown Bank area ( $52^{\circ} 32^{\prime}$ 59.994" North, $3^{\circ} 18^{\prime} 36.400^{\prime \prime}$ East; Fig. 1a). The Brown Bank area is characterized by a large, north-south oriented sandbank. The water depth at the top of the bank is $19 \mathrm{~m}$; deep troughs with a water depth of $45 \mathrm{~m}$ are found on both sides of the crest (Fig. 1b). Similarly oriented but less elevated sandbanks dominate the surroundings (Knaapen, 2009). Formed by the (stable) north-south oriented tidal currents, these sandbanks are kilometres long, tens of meters high and around 5-10 km apart from each other (Knaapen, 2009). Sandbank crests, slopes, and troughs are comprised of contrasting sediments and fauna. van Dijk et al., 2012 described the fauna as a function of the geomorphology and found well-sorted, medium sand at the crests and muddy sediments mixed with gravel and shell fragments in the troughs. Infauna species diversity and abundance was much higher in the troughs than on the crests. The slopes were a mix of these two extremes (van Dijk et al., 2012). According to van Dijk et al. (2012), sand waves and mega ripples are present on the crests of the sandbanks, with a perpendicular orientation. The sand waves are symmetrical in crosssectional shape, with an average wavelength and height of $190 \mathrm{~m}$ and $2.6 \mathrm{~m}$ respectively (van Dijk et al., 2012).

\subsection{Video footage}

Video footage was collected with a Remotely Operated Vehicle (ROV), Saab Seaeye Falcon DR (Saab Seaeye Ltd., Saab North America Inc), equipped with two forward-facing video cameras: (1) a high-definition camera with $1920 \times 1080$ px resolution, 1/2.9" Exmor R CMOS Sensor, minimum scene illumination of 3-11 Lux, and a $4-48 \mathrm{~mm}, \mathrm{f} /$ 1.8-3.4 zoom lens; and (2) a low-definition camera with a resolution of 540 TVL, $1 / 2^{\prime \prime}$ interline transfer CCD sensor, sensitivity of $0.35 \mathrm{Lux}$, and a $1 / 2^{\prime \prime}$ aspherical, wide-angle, fixed-focus lens. The high definition camera could be repositioned remotely by the operators (both pilot and scientists) and was used to shoot selective high-quality photos and video-fragments. Moreover, a continuous video of lower quality was separately recorded by the camera. The second camera was mounted on top of the ROV and looked forward with an oblique angle to the seabed. This camera recorded continuously. So for each ROV track, we had two continuous videos (with differing viewing angles) and several highquality video-fragments. The track of the ROV was constantly recorded by a TrackLink 1500 system (LinkQuest Inc., San Diego, USA) that registered the exact location of the ROV in relation to the vessels' location. The course of the ROV depended on the prevailing currents and decisions of the operators.

Five ROV dives were made in total, of which four were at a random location within the Brown Bank area. The fifth dive was taken at the same reef as discovered during the first dive. The video footage was not collected according to scientific operational guidelines (Coggan et al., 2007; Hitchin et al., 2015) as this was intended as an exploratory characterisation survey, disallowing for the application of a standard scientific video analysis method. Hence, we developed an appropriate protocol to analyse the videos, based loosely on the standard video analysis guidelines (Hendrick and Foster-Smith, 2006). All five videos were analysed twice, by two independent observers. Results shown are 


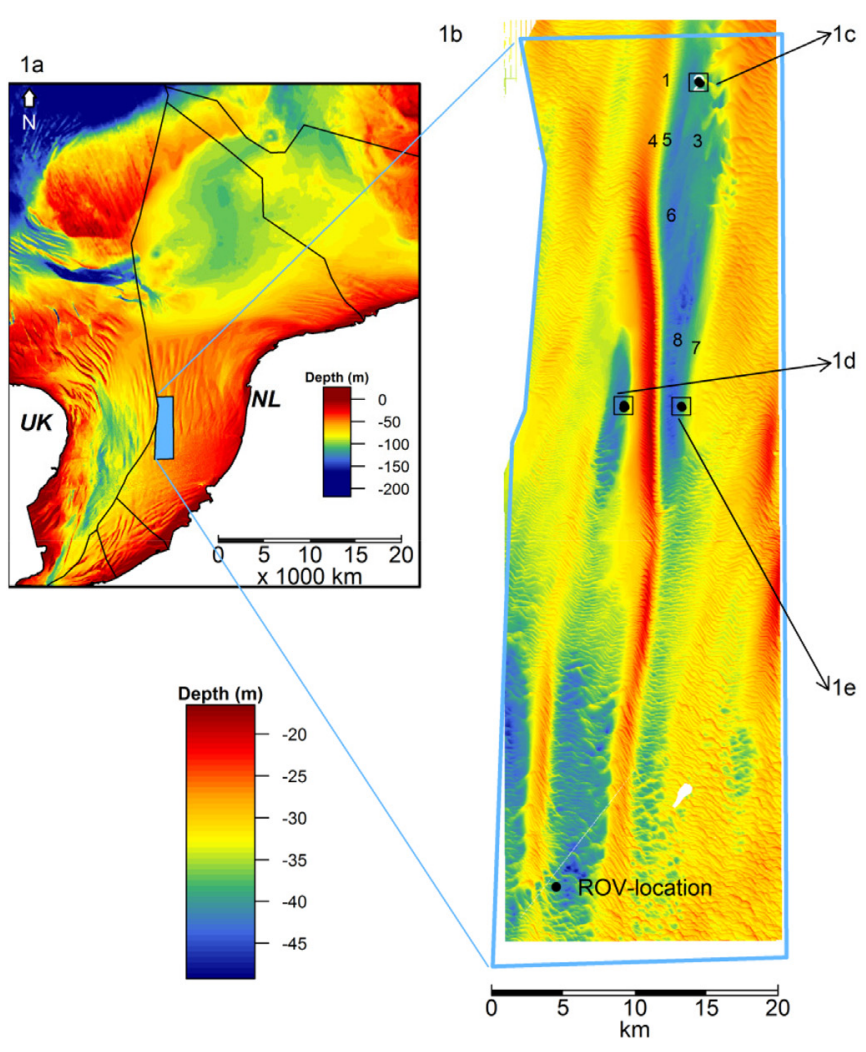

the averages of both observations. For each video, the total time at the seabed was determined, presence of $S$. spinulosa was recorded, and reef structure was assessed. In line with the OSPAR recommendations (OSPAR Commission, 2013), we classified S. spinulosa as a reef if its structure had a general elevation of $>5 \mathrm{~cm}$ above the seabed and a local coverage of $>30 \%$ of the seabed. All other recordings of $S$. spinulosa were scored as 'low abundance'. The continuous video enabled us to identify and count organisms larger than $5 \mathrm{~cm}$. From the highquality video fragments, however, we could frequently identify smaller organisms as well. All species observations were registered per habitat type: $S$. spinulosa reef, $S$. spinulosa in low abundance, or adjacent area.

The TrackLink system yielded GPS positions of the ROV for every second. Based on the time registration, we could link GPS positions to the video analysis. This resulted in the exact route of the ROV near the seabed and GPS positions of $S$. spinulosa observations. Due to the meandering course and varying depth and speed of the ROV, the observed surface of the seabed differed during the ROV-track. Therefore, we plotted the ROV positions over a $1 \mathrm{~m}^{2}$ grid. The total observed surface covered in a video was then estimated as the total number of grid cells with ROV positions, while the ROV was at the seabed. We similarly estimated the area with $S$. spinulosa present and the total reef extent for the ROV surveyed area. Unfortunately, the TrackLink system log-system crashed after a few minutes during the second dive, resulting in missing GPS-positions for the rest of this video. In the low-quality video however, the GPS-positions are displayed on the screen as well. From this video, we have registered the GPS-position for every $15 \mathrm{~s}$ of the dive. Plotting both the logged and video-based GPS-positions showed four outliers, which were located $>100 \mathrm{~m}$ apart from the other GPS-locations. These outliers were most likely caused by errors in the TrackLink system. We removed the four outliers and subsequently analysed the remaining ROV-positions as described.

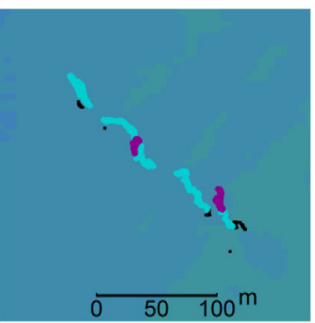

Fig. 1. The location of the Brown Bank area within the Southern North Sea (a) and a high-resolution bathymetry map of the Brown Bank area depicting the locations of the sediment samples (1-8) and ROVtransects (dots) (b). Location of acoustic data collected in this survey is depicted in black lines. S. spinulosa presence, including reef condition (reef structure versus low abundances), are shown for the four separate ROV-locations $(1 c-1 f)$. (For interpretation of the references to colour in this figure legend, the reader is referred to the web version of this article.)

\subsection{Acoustics}

Acoustic surveys of the seabed were performed with a hull-mounted Reson Seabat 7125 multi-beam echo-sounder (MBES). The MBES operated at $200 \mathrm{kHz}$ and had $2^{\circ}$ and $1^{\circ}$ beam opening angles in the along and across track directions respectively. The beam coverage of the 256 beams was set to equidistant (vs. equiangular) with a maximum ping rate of $50 \mathrm{~Hz}$ and a pulse length of $300 \mu \mathrm{s}$. Both bathymetry and backscatter data were recorded using Qinsy. A Kongsberg Seatex DPS 200 global positioning system (GPS) provided position information and the MBES data was motion corrected by use of a Seatronics POS MV 320 motion reference unit (MRU).

The MBES data collected was very noisy, perhaps because the MBES was approaching its service cycle. The data noise was cleaned in a three-step process. First, extreme depth outliers were removed in Qinsy using the 3D-editing tool. Second, Qinsy's automated cleaning tool 'Qloud' was applied to eliminate the majority of the faulty depth soundings. As a last step, all the data was again reviewed in the 3Dediting tool to remove aeration spikes and other small defects not corrected by 'Qloud'. A roll offset that was noticed in post processing was also corrected for.

After cleaning, the acoustic data was exported in custom ASCII format. In MatLab, the acoustic backscatter data was classified with the Bayes algorithm (Snellen et al., 2018; Simons and Snellen, 2009; Eleftherakis et al., 2012, 2014; Alevizos et al., 2015). Due to the steep slopes on the sand waves, a slope correction step was performed to eliminate grazing angle effects on the classification results. This slope correction was performed by first gridding the data into square grid cells containing ten data points per grid cell on average. Size of the grid cells varied between survey lines, but was restricted between $0.25 \times 0.25 \mathrm{~m}$ and $5 \times 5 \mathrm{~m}$, with most grid cells having a size between $0.75 \times 0.75 \mathrm{~m}$ and $1.25 \times 1.25 \mathrm{~m}$. A digital terrain model was created by taking the mode depth of all points in the grid cells, which was then used to calculate the slope per grid cell by applying the average 
maximum technique (Burrough and McDonnell, 1998) to the eight neighbouring grid cells. The true grazing angle was calculated as the angle between the vector from a given data point $d$ to the source (transducer) $s$ and the vector from $d$ to a point $n$. Where $n$ is on the plane $p$, passing through $d$ having the same slope as calculated for the grid cell within which $d$ lies, and the line $m$ perpendicular to $p$ passing through $s$.

\subsection{Sediment samples}

Sediment sample locations were selected following assessment of preliminary acoustic data and at random locations within the area of interest. Sampling was conducted with a $12 \mathrm{~L}$ van Veen grab, with a surface area of around $880 \mathrm{~cm}^{2}$. Representative subsamples acquired for particle size analysis were immediately stored in plastic bags at $-20^{\circ} \mathrm{C}$ until processed. The samples were freeze dried for 4 days, homogenized, and subsampled for the determination of sediment grain size, total organic carbon and nitrogen content. To determine sediment grain size, subsamples were sieved over a $1 \mathrm{~mm}$ mesh sieve and analysed by means of a laser diffraction technique using a Malvern Mastersizer 2000 (Malvern Instruments, Worcestershire, UK). The $>1 \mathrm{~mm}$ fraction was not included in the analysis. Results were verified using two internal control samples, in accordance with the UK National Marine Biological Quality Control Scheme (NMBAQC).

Organic carbon and total nitrogen content were analysed according to the Dumas method (Nieuwenhuize et al., 1994), using a Thermo Flash 2000 Element Analyser (Thermo Scientific). Freeze-dried subsamples were measured and subsequently oxidized at high temperature $\left(1020^{\circ} \mathrm{C}\right)$ with excessive oxygen supply and oxidation catalysts. This produced $\mathrm{CO}_{2}$ and nitrous oxides $\left(\mathrm{NO}_{\mathrm{x}}\right)$, of which the latter were reduced to $\mathrm{N}_{2}$ over copper grains at $650^{\circ} \mathrm{C}$. Both gasses were separated using gas chromatography and total amounts were determined by thermal conductivity. Samples containing inorganic carbon were acidified before analysis to remove the inorganic carbon.

\subsection{Fisheries}

Satellite data of Dutch demersal fisheries (all vessels $>12 \mathrm{~m}$ ) were obtained from the Dutch Ministry of Agriculture, Nature and Food Quality for the years 2008-2015. These data comprised satellite recordings of date, time, position, heading, and speed of the vessel, with an interval of around two hours. In addition, daily logbook information was available, which included the date, general position, and fishing gear of the vessel. Satellite positional data was merged with daily logbook information, coupling the unique combination of date and vessel within a fishing trip (Hintzen et al., 2012). This yielded one dataset, comprising both spatial and fisheries-technical data. Based on the speed and fishing gear, each satellite recording was identified as 'steaming', 'floating', or 'fishing'. If a recording was determined as 'floating' in between two 'fishing' recordings, the floating recording was re-identified to 'fishing' to correct for setting and heaving of the fishing gear (van Denderen et al., 2015). Then, for each 'fishing' ping, the swept area was calculated, as the product of speed $(\mathrm{km} / \mathrm{h})$, fishing time $(\mathrm{h})$, and the width of the gear (km) (Piet and Hintzen, 2012). At a resolution of $1 \times 1 \mathrm{~km}$, total annual swept area was aggregated for all demersal fisheries and divided by the surface of the grid cell $\left(1 \mathrm{~km}^{2}\right)$. This fishing intensity (yearly swept area) was then averaged for the 8 years of the study period, resulting in an average fishing intensity distribution. For the main fishing method present in the area (beam-trawlers with a mesh size between 70 and $99 \mathrm{~mm}$ ), the heading during fishing was determined for all VMS-pings classified as 'fishing' in three depth classes.

\section{Results}

\subsection{Video footage}

S. spinulosa was observed in four of the five video transects, located at three separate locations within the troughs of the Brown Bank area (Fig. 1a-b). Altogether, the videos had a total seabed recording time of $164 \mathrm{~min}$ and $3 \mathrm{~s}$ (45:14, 26:08, 25:23, 46:44, 20:34 [minutes: seconds]), a total transect length of around $7.5 \mathrm{~km}(3124 \mathrm{~m}, 1665 \mathrm{~m}, 885 \mathrm{~m}$, $1344 \mathrm{~m}, 523 \mathrm{~m})$, and an observed area of $1995 \mathrm{~m}^{2}\left(1063^{2} \mathrm{~m}^{2}, 86 \mathrm{~m}^{2}\right.$, $399 \mathrm{~m}^{2}, 447 \mathrm{~m}^{2}$ ). An area of $1603 \mathrm{~m}^{2}$ was observed with $S$. spinulosa present, which is $80 \%$ of the total surveyed area. Based on the OSPAR recommendations ( $>30 \%$ coverage and $>5 \mathrm{~cm}$ elevation from the seabed), an area of $1023 \mathrm{~m}^{2}$ (51\%) was classified as $S$. spinulosa reef (Fig. 2). Of the four observed locations, the most northern location identified mainly $S$. spinulosa in low abundances (Fig. 1c). From the $344 \mathrm{~m}^{2}$ with $S$. spinulosa present, only $72 \mathrm{~m}^{2}$ was classified as reef (21\%). At the middle location, the ROV did not reveal the presence of any $S$. spinulosa (Fig. 1d). The two southern locations comprised $S$. spinulosa observations, including extensive reef structures (Fig. 1e-f). At the eastern location, $44 \%$ was classified as reef $\left(165 \mathrm{~m}^{2}\right.$ out of $\left.376 \mathrm{~m}^{2}\right)$. The western location showed the highest percentage of reef structures present $\left(89 \%, 786 \mathrm{~m}^{2}\right.$ out of the $\left.883 \mathrm{~m}^{2}\right)$. For all three locations with $S$. spinulosa reefs, the video footage suggested that the $S$. spinulosa reefs were dominantly located in local depressions of the seabed, as the seabed became elevated at the border of $S$. spinulosa reefs, comprising a sandy plateau with sand ripples.

Thirty different organisms were identified from the continuous video and the high-quality video fragments (Table 1). Some of the organisms could only be identified to order level such as anemones (Actiniaria) and sea squirts (Ascidiacea). For all other species, the enumerated individuals were translated to abundance classes of the SACFOR scale, ${ }^{3}$ using the calculated extent of the observed surface. Hermit crab (Pagurus bernhardus), common starfish (Asterias rubens), dragonet (Callionymus spp.), and swimming crab (Liocarcinus spp.) were present at all locations, with a slightly higher density in the $S$. spinulosa reefs compared to adjacent areas. Other species, like the small-spotted catshark (Scyliorhinus canicula), rock gunnel (Pholis gunnellus), edible crab (Cancer pagurus) and the velvet crab (Necora puber) were less abundant or absent at some of the locations. Moreover, these species were almost exclusively observed in areas of $S$. spinulosa reefs. The longclawed porcelain crab (Pisidia longicornis) was too small to be observed from the continuous footage, but several high-quality video fragments showed that this species was massively abundant between the $S$. spinulosa tubes within the reefs. Drifting algae and bivalves on top of the seabed were excluded, as they were not attached or probably dead.

\subsection{Acoustics}

The acoustic survey consisted of two main lines perpendicular to the Brown Bank, extending $7 \mathrm{~km}$ west and $9 \mathrm{~km}$ east of the Brown Bank, and one east-west line of $6.22 \mathrm{~km}$ covering only the Brown Bank and the troughs on either side of the Brown Bank (Fig. 3a). In addition to the east-west lines, there are five sets of three crosslines that intersect with the east-west lines and have a length of $1.6 \mathrm{~km}$ each. The sets of crosslines are in the troughs on either side of the Brown Bank, on the Brown Bank crest, on the eastern slope of the eastern trough, and on the sand wave plateau to the east of the Brown Bank. The acoustic lines cover the two most southern locations with $S$. spinulosa present. No acoustic data of sufficient quality was recorded for the other two ROV

\footnotetext{
${ }^{2}$ This is the summation of videos 1 and 5 , as they partly covered the same location.

${ }^{3}$ Marine Nature Conservation Review (MNCR) SACFOR abundance scale. http://jncc.defra.gov.uk/page-2684
} 


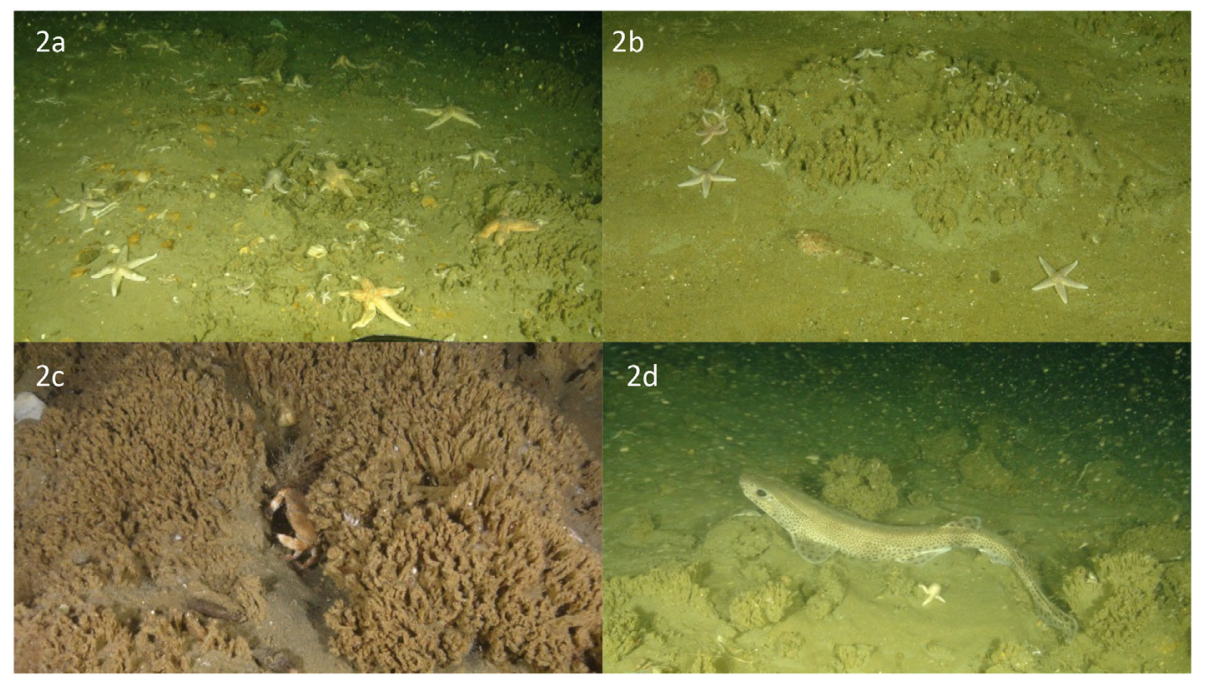

Fig. 2. Pictures of the S. spinulosa reefs in low abundance (a,b) and reef structure (c,d), with associated species (a: Common starfish (Asterias rubens); b: Common starfish (A. rubens) and dragonets (Callionymus spp.); c: Edible crab (Cancer pagurus); d: Small-spotted catshark (Scyliorhinus canicula)).

Table 1

Video observed organisms, with species abundance estimates for the three observed habitat types (S. spinulosa reefs (SR), Low abundances of S. spinulosa (LA), and adjacent areas with sandy sediments (Aa)). The location of the video is given in parentheses, referring to Fig. 1. Species abundances are presented in SACFOR abundance classes with (S) 1-9 individuals per $0.1 \mathrm{~m}^{2}$, (A) 1-9 individuals per $1 \mathrm{~m}^{2}$, (C) 1-9 individuals per $10 \mathrm{~m}^{2}$, (F) 1-9 individuals per $100 \mathrm{~m}^{2}$, (O) $1-9$ individuals per $1000 \mathrm{~m}^{2},(\mathrm{R})<1$ individuals per $1000 \mathrm{~m}^{2}$. If no abundance estimate could be determined, but the species is observed in the transect, presence (P) of that species is registered.

\begin{tabular}{|c|c|c|c|c|c|c|c|c|c|c|c|c|c|c|c|c|}
\hline \multirow[t]{2}{*}{ Common name } & \multirow[t]{2}{*}{ Scientific name } & \multicolumn{3}{|c|}{ Video 1 (1e) } & \multicolumn{3}{|c|}{ Video 2 (1d) } & \multicolumn{3}{|c|}{ Video 3 (1c) } & \multicolumn{3}{|c|}{ Video 4 (1f) } & \multicolumn{3}{|c|}{ Video 5 (1e) } \\
\hline & & SR & LA & Aa & SR & LA & $\mathrm{Aa}$ & SR & LA & $\mathrm{Aa}$ & SR & LA & $\mathrm{Aa}$ & SR & LA & Aa \\
\hline Small-spotted catshark & Scyliorhinus canicula & $\mathrm{O}$ & $\mathrm{F}$ & $\mathrm{O}$ & - & - & - & - & - & - & - & - & - & $\mathrm{F}$ & $\mathrm{F}$ & - \\
\hline Dragonet & Callionymus spp. & $\mathrm{F}$ & $\mathrm{C}$ & $\mathrm{O}$ & - & - & $\mathrm{C}$ & $\mathrm{F}$ & $\mathrm{F}$ & $\mathrm{F}$ & $\mathrm{C}$ & $\mathrm{C}$ & $\mathrm{F}$ & $\mathrm{F}$ & $\mathrm{F}$ & - \\
\hline Hooknose & Agonus cataphractus & - & - & - & - & - & - & $\mathrm{O}$ & $\mathrm{O}$ & - & $\mathrm{O}$ & - & - & - & - & - \\
\hline Rock gunnel & Pholis gunnellus & - & - & - & - & - & - & - & - & - & $\mathrm{F}$ & - & - & - & - & - \\
\hline Gobies & Gobiidae & $\mathrm{P}$ & $\mathrm{P}$ & $\mathrm{P}$ & $\mathrm{P}$ & $\mathrm{P}$ & $\mathrm{P}$ & $\mathrm{P}$ & $\mathrm{P}$ & $\mathrm{P}$ & $\mathrm{P}$ & $\mathrm{P}$ & $\mathrm{P}$ & $\mathrm{P}$ & $\mathrm{P}$ & $\mathrm{P}$ \\
\hline Greater pipefish & Syngnathus acus & $\mathrm{O}$ & - & - & - & - & - & - & - & - & - & - & - & - & - & - \\
\hline Snake pipefish & Entelurus aequoreus & - & - & - & - & - & - & - & - & - & $\mathrm{O}$ & - & - & - & - & - \\
\hline- & Trisopterus sp. & $\mathrm{R}$ & - & - & - & - & - & - & - & - & - & - & - & - & - & - \\
\hline Lesser weever & Echiichthys vipera & & & & - & - & $\mathrm{F}$ & - & - & - & - & - & - & - & - & - \\
\hline Flatfishes $^{\mathrm{a}}$ & Pleuronectiformes ${ }^{a}$ & $\mathrm{O}$ & $\mathrm{F}$ & $\mathrm{O}$ & - & - & $\mathrm{C}$ & $\mathrm{F}$ & $\mathrm{O}$ & - & $\mathrm{F}$ & $\mathrm{F}$ & $\mathrm{O}$ & - & - & $\mathrm{F}$ \\
\hline Solenette & Buglossidium luteum & $\mathrm{P}$ & - & - & - & - & $\mathrm{P}$ & - & - & - & - & $\mathrm{P}$ & $\mathrm{P}$ & - & - & - \\
\hline Scaldfish & Arnoglossus laterna & - & - & - & - & - & - & $\mathrm{P}$ & $\mathrm{P}$ & - & - & $\mathrm{P}$ & - & - & - & - \\
\hline Lemon sole & Microstomus kitt & - & - & - & - & - & - & - & - & - & $\mathrm{P}$ & - & - & - & - & - \\
\hline $\mathrm{Dab}$ & Limanda limanda & $\mathrm{P}$ & $\mathrm{P}$ & $\mathrm{P}$ & - & - & $\mathrm{P}$ & - & $\mathrm{P}$ & - & $\mathrm{P}$ & $\mathrm{P}$ & $\mathrm{P}$ & $\mathrm{P}$ & - & $\mathrm{P}$ \\
\hline Dover sole & Solea solea & - & - & & - & - & - & - & - & - & - & $\mathrm{P}$ & - & - & - & - \\
\hline Common starfish & Asterias rubens & $\mathrm{C}$ & A & $\mathrm{C}$ & - & - & $\mathrm{C}$ & $\mathrm{C}$ & $\mathrm{C}$ & $\mathrm{F}$ & A & A & $\mathrm{C}$ & A & $\mathrm{C}$ & $\mathrm{C}$ \\
\hline Serpent star & Ophiura spp. & $\mathrm{O}$ & - & $\mathrm{F}$ & - & - & C & - & $\mathrm{O}$ & $\mathrm{F}$ & $\mathrm{F}$ & $\mathrm{C}$ & $\mathrm{C}$ & $\mathrm{F}$ & $\mathrm{F}$ & $\mathrm{C}$ \\
\hline Hermit crab & Pagurus bernhardus & $\mathrm{F}$ & $\mathrm{C}$ & - & - & - & $\mathrm{F}$ & - & $\mathrm{F}$ & - & $\mathrm{F}$ & $\mathrm{F}$ & $\mathrm{F}$ & C & $\mathrm{F}$ & $\mathrm{F}$ \\
\hline Swimming crab & Liocarcinus spp. & $\mathrm{F}$ & $\mathrm{C}$ & - & - & - & $\mathrm{F}$ & $\mathrm{C}$ & $\mathrm{C}$ & $\mathrm{F}$ & $\mathrm{C}$ & $\mathrm{F}$ & $\mathrm{F}$ & $\mathrm{F}$ & $\mathrm{F}$ & - \\
\hline Edible crab & Cancer pagurus & $\mathrm{F}$ & $\mathrm{F}$ & - & - & - & - & - & $\mathrm{O}$ & - & $\mathrm{F}$ & $\mathrm{O}$ & $\mathrm{O}$ & - & - & - \\
\hline Velvet crab & Necora puber & $\mathrm{F}$ & $\mathrm{F}$ & - & - & - & - & $\mathrm{F}$ & - & - & $\mathrm{C}$ & $\mathrm{F}$ & - & $\mathrm{F}$ & - & - \\
\hline- & Atelecyclus undecimdentatus & - & - & - & - & - & - & - & $\mathrm{P}$ & - & $\mathrm{F}$ & - & - & - & - & - \\
\hline Long-legged spider crab & Macropodia spp. & $\mathrm{F}$ & - & - & - & - & $\mathrm{F}$ & - & - & - & $\mathrm{F}$ & - & $\mathrm{F}$ & $\mathrm{O}$ & - & - \\
\hline Long-clawed porcelain crab & Pisidia longicornis & $\mathrm{P}$ & $\mathrm{P}$ & - & - & - & - & $\mathrm{P}$ & $\mathrm{P}$ & - & $\mathrm{P}$ & $\mathrm{P}$ & - & $\mathrm{P}$ & $\mathrm{P}$ & - \\
\hline Ghost shrimp & Caprella sp. & $\mathrm{P}$ & - & - & - & - & - & $\mathrm{P}$ & - & - & $\mathrm{P}$ & $\mathrm{P}$ & - & $\mathrm{P}$ & - & - \\
\hline Shrimp & Eualus spp. & - & - & - & - & - & - & - & - & - & $\mathrm{P}$ & - & - & - & - & - \\
\hline Anemones & Sagartia spp. & $\mathrm{P}$ & $\mathrm{P}$ & - & - & - & - & $\mathrm{P}$ & $\mathrm{P}$ & - & $\mathrm{P}$ & $\mathrm{P}$ & - & $\mathrm{P}$ & $\mathrm{P}$ & - \\
\hline Sea squirts & Ascidiacea & $\mathrm{P}$ & - & - & - & - & - & - & - & - & $\mathrm{P}$ & - & - & $\mathrm{P}$ & - & - \\
\hline Common flower-head & Ectopleura larynx & $\mathrm{P}$ & - & - & - & - & - & $\mathrm{P}$ & $\mathrm{P}$ & - & $\mathrm{P}$ & $\mathrm{P}$ & $\mathrm{P}$ & $\mathrm{P}$ & - & - \\
\hline Sand mason worm & Lanice conchilega & - & - & $\mathrm{P}$ & - & - & $\mathrm{P}$ & - & $\mathrm{P}$ & $\mathrm{P}$ & - & $\mathrm{P}$ & $\mathrm{P}$ & $\mathrm{P}$ & $\mathrm{P}$ & $\mathrm{P}$ \\
\hline Snailfur & Hydractinia echinata & $\mathrm{P}$ & $\mathrm{P}$ & $\mathrm{P}$ & - & - & $\mathrm{P}$ & - & $\mathrm{P}$ & - & $\mathrm{P}$ & $\mathrm{P}$ & $\mathrm{P}$ & $\mathrm{P}$ & $\mathrm{P}$ & $\mathrm{P}$ \\
\hline Sea beard & Nemertesia antennina & $\mathrm{P}$ & - & - & - & - & - & - & - & - & - & - & - & - & - & - \\
\hline Sickle hydroid & Hydrallmania falcata & - & - & - & - & - & - & $\mathrm{P}$ & - & - & - & - & - & - & - & - \\
\hline
\end{tabular}

${ }^{a}$ Pleuronectiformes comprise all flatfish species. No abundance estimate is given for single species, as not all flatfish species could be identified to species level. Those that have been identified to species level are classified as present $(\mathrm{P})$. 
$3 a$

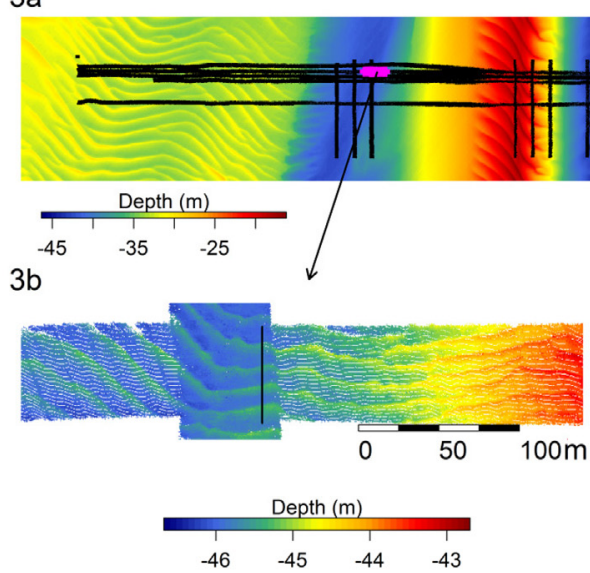

$3 d$

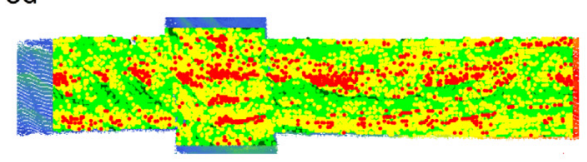

Fig. 3. Acoustic data collected at the Brown Bank in the vicinity of the two most southern ROV locations. In (a), an overview of the data is presented, with the performed acoustic transects depicted with black lines, and white dots representing the mean centre of the ROV-track. The two sections of interest are highlighted in pink (a) and enlarged (b, c), showing the high-resolution bathymetry, including the videobased S. spinulosa reefs (pink dots). The depth profile along the two transects depicted with brown lines in (b) and (c) is given in (d) and (e) respectively, with the length of the transect $(\mathrm{m})$ on the $\mathrm{x}$-axis and the depth (m) on the y-axis. Habitat classification results of the acoustic data of (b) and (c) are respectively shown in (f) and (g). Both also include the S. spinulosa reef observations (pink dots) and the depthprofile transects (brown line). (For interpretation of the references to colour in this figure legend, the reader is referred to the web version of this article.)

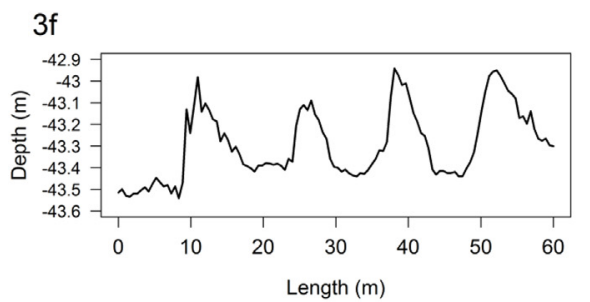

$3 f$

locations.

The collected bathymetry data has a high-resolution $(0.5 \mathrm{~m})$ and confirms the presence of both large scale sandbank-structures and the smaller, perpendicular sand waves. Moreover, in addition to the described sand waves on the large-scale sandbank crests, our bathymetry data showed the presence of even smaller sand waves in the large-scale sandbank troughs. The multibeam data did not show any trawl marks, nor the presence of $S$. spinulosa reef structures.

The most western location with $S$. spinulosa reefs observed was characterized as an area of around $39-43 \mathrm{~m}$ depth with east-west oriented sand waves (Fig. 3b). These small-scale sand waves were generally around $13 \mathrm{~m}$ apart from each other and had a height difference of around $30 \mathrm{~cm}$ (Fig. 3d). The most eastern location with $S$. spinulosa reefs observed was a little deeper, around $43-45 \mathrm{~m}$ of water depth (Fig. 3c). The small-scale sand wave pattern was present here as well, but oriented in a slightly northeast-southwest direction. Moreover, the sand waves seemed smaller, both in wavelength (around $10 \mathrm{~m}$ ) and in height difference $(15-20 \mathrm{~cm}$ ) (Fig. 3e). At both locations, the $S$. spinulosa reefs were dominantly located within the valleys between the sand waves (Figs. $3 \mathrm{~b}$ and c).

The Bayes algorithm identified 4 distinct classes in backscatter, with class 1 showing lower reflectivity than class 4 . Acoustic reflectivity is an indicator for sediment composition, with higher reflectivity being related to coarse sediments or sediments with high roughness. Acoustic signatures of biogenic reef structures can therefore show increased reflectivity (Manik, 2016). A more detailed examination of the acoustic classification of the two southern $S$. spinulosa locations showed that the areas overall are classified as acoustic class 2 (Fig. $3 \mathrm{f}$ and $\mathrm{g}$ ). The crests or slopes of sand waves appeared almost solely the less reflective class 1 , while the sand wave valleys were categorized as the higher reflective classes 3 and 4 . This suggests that the sand wave valleys probably comprise $S$. spinulosa reefs and coarser sediments than the slopes and crests.

\subsection{Sediment samples}

A total of eight sediment samples were analysed (Fig. 1a). Sampled sediments were dominated by medium sand $(250-500 \mu \mathrm{m}$; Table 2$)$. However, some differences between the crest (stations $1,4,5)$ and trough (stations $2,3,6,7,8$ ) could be observed. Proportions of fine sand $(125-250 \mu \mathrm{m})$ were in general higher at the crests [Trough: $25.7 \% \pm 15.5 \%$. Crest: $45.0 \% \pm 3.4 \%$. (Mean \pm SD)]. The coarse particles $(500-1000 \mu \mathrm{m})$ showed an opposite pattern, with higher fractions in the troughs [Trough: $12.7 \% \pm 8.4 \%$. Crest: $0.6 \% \pm 0.1 \%]$. The stations in the troughs congruently had a slightly higher median grain size [Trough: $319.27 \pm$ 45.09. Crest: $258.84 \pm 6.52$ ] and higher $90 \%$ quantile [Trough: $524.51 \pm 104.58$. Crest: $374.18 \pm 2.12$ ]. The large variation in particle grain size between the trough stations was caused by station 6 , which had a relative high fraction of very fine $(62.5-125 \mu \mathrm{m})$ particles (Table 2). Organic and chemical content did not vary considerably between the stations (Table 2).

\subsection{Fisheries}

The Brown Bank area was intensively fished in the period 2008-2015 by Dutch demersal fisheries (Fig. 4a-b). Fisheries were concentrated in the large-scale sandbank troughs, with an average fishing intensity of $>5$ times per year. Fishing intensity on the largescale sandbank crests was on average lower than 2 times per year. Fishing intensity differed at the four observed locations. At the most northern location of observed S. spinulosa, fishing intensity was highest ( $>10$ times per year; Fig. 4a-b). The other locations were subject to lower fishing intensities; the location in the western trough had a fishing intensity of 1-2 times per year, while both locations in the eastern trough showed an intensity of 5-10 times per year.

The majority of all fishing activity (93\%) was comprised of beam- 
Table 2

Granulometric, organic and chemical composition of the sediment samples. The columns "all" represent the mean and SD for that location (Crest or Trough).

\begin{tabular}{|c|c|c|c|c|c|c|c|c|c|c|c|}
\hline \multirow[t]{2}{*}{ Parameters } & \multirow{2}{*}{$\begin{array}{l}\text { Location } \\
\text { Station }\end{array}$} & \multicolumn{4}{|l|}{ Crest } & \multicolumn{6}{|l|}{ Trough } \\
\hline & & 1 & 4 & 5 & All & 2 & 3 & 6 & 7 & 8 & All \\
\hline \multicolumn{2}{|c|}{ Median grain size $(\mu \mathrm{m})$} & 260.04 & 264.68 & 251.80 & $258.84 \pm 6.52$ & 344.89 & 319.88 & 242.80 & 357.89 & 330.90 & $319.27 \pm 45.09$ \\
\hline \multicolumn{2}{|c|}{ Median grain size (phi) } & 1.94 & 1.92 & 1.99 & $1.95 \pm 0.04$ & 1.54 & 1.64 & 2.04 & 1.48 & 1.60 & $1.66 \pm 0.22$ \\
\hline \multicolumn{2}{|c|}{ Modus grain size $(\mu \mathrm{m})$} & 259.83 & 264.58 & 251.76 & $258.72 \pm 6.48$ & 352.69 & 324.94 & 242.69 & 356.91 & 321.98 & $319.84 \pm 45.92$ \\
\hline \multicolumn{2}{|c|}{0.1 quantile $(\mu \mathrm{m})$} & 181.76 & 185.82 & 170.15 & $179.24 \pm 8.13$ & 189.63 & 198.38 & 157.95 & 249.45 & 171.11 & $193.30 \pm 35.12$ \\
\hline \multicolumn{2}{|c|}{0.9 quantile $(\mu \mathrm{m})$} & 372.52 & 376.57 & 373.45 & $374.18 \pm 2.12$ & 595.27 & 492.48 & 373.74 & 514.55 & 646.50 & $524.51 \pm 104.58$ \\
\hline \multicolumn{12}{|c|}{ Sediment fractions (\%) } \\
\hline \multicolumn{2}{|c|}{ Coarse $(500-1000 \mu \mathrm{m})$} & 0.54 & 0.56 & 0.71 & $0.60 \pm 0.09$ & 19.80 & 9.18 & 0.85 & 11.99 & 21.66 & $12.70 \pm 8.43$ \\
\hline \multicolumn{2}{|c|}{ Medium $(250-500 \mu \mathrm{m})$} & 54.91 & 57.43 & 50.20 & $54.18 \pm 3.67$ & 56.13 & 66.15 & 45.81 & 77.87 & 49.07 & $59.01 \pm 13.12$ \\
\hline \multicolumn{2}{|c|}{ Fine $(125-250 \mu \mathrm{m})$} & 44.45 & 41.92 & 48.62 & $45.00 \pm 3.38$ & 20.57 & 21.26 & 51.71 & 10.15 & 24.94 & $25.73 \pm 15.53$ \\
\hline \multicolumn{2}{|c|}{ Very fine $(62.5-125 \mu \mathrm{m})$} & 0.10 & 0.09 & 0.48 & $0.22 \pm 0.22$ & 0.13 & 0.00 & 1.63 & 0.00 & 0.57 & $0.47 \pm 0.69$ \\
\hline \multicolumn{2}{|c|}{ Silt $(<63 \mu \mathrm{m})$} & 0.00 & 0.00 & 0.00 & $0.00 \pm 0.00$ & 3.38 & 3.4 & 0.00 & 0.00 & 3.76 & $2.11 \pm 1.93$ \\
\hline \multicolumn{12}{|c|}{ Organic and chemical composition } \\
\hline \multicolumn{2}{|c|}{ Organic carbon $(\%)$} & 6.53 & 4.92 & 12.31 & $7.92 \pm 3.89$ & 8.00 & 8.35 & 8.09 & 3.86 & 7.90 & $7.24 \pm 1.90$ \\
\hline \multicolumn{2}{|c|}{ Total Nitrogen (\%) } & 1.14 & 0.99 & 2.07 & $1.40 \pm 0.59$ & 1.40 & 1.32 & 1.45 & 0.95 & 1.13 & $1.25 \pm 0.21$ \\
\hline \multicolumn{2}{|c|}{ Ratio C:N } & 6.69 & 5.80 & 6.95 & $6.48 \pm 0.60$ & 6.65 & 7.37 & 6.52 & 4.76 & 8.18 & $6.70 \pm 1.27$ \\
\hline
\end{tabular}

trawlers with a mesh size between 70 and $99 \mathrm{~mm}$, with limited activity of flyshooters (5\%), beam-trawlers with a different mesh size (1\%), and otter-trawlers (1\%; data not shown). The main fishing direction depended on the water depth, with equal percentages of west-, east- and southwards headed pings for water depths above $30 \mathrm{~m}$ (Fig. 4c). For the deeper waters in the large-scale sandbank troughs (40-50 m), however, north and south oriented pings were dominant.

\section{Discussion}

Three extensive $S$. spinulosa reefs were discovered serendipitously at three separate locations within the large-scale sandbank troughs of the intensively fished Brown Bank area of the Dutch continental shelf. $S$. spinulosa reefs are restricted to areas with sufficient suspended sand grains, as the polychaetes require these for the building of their tubes. Hence, the reefs are located in turbid areas with a constant supply of sand grains (Jones et al., 2000). Apparently, the troughs of such largescale sandbanks provide a suitable habitat for $S$. spinulosa, which is congruent with the observations of $S$. spinulosa reefs in the troughs of the North Norfolk Sandbanks in UK waters (Jenkins et al., 2015). The two southern locations comprised aggregated structures that generally met the OSPAR recommendations for $S$. spinulosa reef classification ( $>30 \%$ cover and $>5 \mathrm{~cm}$ elevation from the seabed), whereas the observed $S$. spinulosa in the northern location was predominantly classified as low abundance.

The discovery of these $S$. spinulosa reefs is remarkable as biogenic reefs are assumed to be vulnerable to physical disturbances (Gibb et al., 2014; OSPAR Commission, 2013), and the observed reefs are located in an intensively fished area. This raises questions about the impact of demersal fisheries on $S$. spinulosa reefs. Using Dutch VMS data, we showed that beam trawlers are very active in this area, with the total fishing intensity potentially even higher as foreign vessels are also allowed to fish in this area. However, considering our minimal estimation of the experienced fishing intensity experienced by the reefs, the question remains how they can persist under this pressure. The location with the most extensive $S$. spinulosa reefs had the lowest fishing intensity. The three other locations, including the one without $S$. spinulosa observed, were subject to higher fishing intensities. This suggests that the reefs are negatively affected by demersal fisheries, but that they nevertheless are able to persist in the presence of this pressure, even when the pressure is high $(>10 \ldots)$.

The only 'experimental' study of fisheries impacts on $S$. spinulosa reefs to date was performed by Vorberg (2000), who measured the loadbearing capacity until fracture of preserved reef fragments and compared those with calculated forces exerted on the seabed by shrimp fishing gears. He concluded that shrimp fisheries are not likely to significantly damage $S$. spinulosa reefs (Vorberg, 2000). Beam-trawlers, the dominant fishing gear used in this area, however, are larger and much heavier than shrimp fishing gear (Eigaard et al., 2017, 2015). Moreover, Vorberg (2000) made his conclusions based on one passing of the fishing gear on a Sabellaria alveolata reef. These reefs have a honeycomb structure, whereas $S$. spinulosa reefs have a highly patchy and irregular structure (Pearce, 2014), making S. spinulosa reefs probably more vulnerable to fishing impacts. In addition, some locations within the large-scale sandbank troughs of the Brown Bank area are subjected to trawling intensities of $>10$ times per year. We therefore conclude that the $S$. spinulosa reefs are likely to be negatively impacted by demersal fishing activities in the Brown Bank area.

The persistence of the observed $S$. spinulosa reefs in this area with high fishing intensities might be explained by the exact location of the reefs in the landscape. In the Belgian Hinder banks area, it was observed that sand wave structures created refuge areas for branching organisms like sponges (Houziaux et al., 2008). Due to the combination of the rigid structure and towing speed of the fishing gear and the sand wave dimensions, the fishing gears did not physically impact the sand wave valleys. Instead, the demersal fishing gears "jumped" from each sand wave top to the next top. This led to refuge areas with high biodiversity in the sand wave valleys (Houziaux et al., 2008). Our video and acoustic bathymetry data showed that most of the $S$. spinulosa reefs were located in small-scale sand wave valleys, within the larger scale troughs. We hypothesize that a similar mechanism protects the valleys between the sand waves of the Brown Bank, enabling the formation and persistence of $S$. spinulosa reefs under fishing pressures that otherwise would destroy S. spinulosa reefs (Fig. 5).

The refuge hypothesis is supported by both acoustic classification and fisheries data. The acoustic data shows that sand wave valleys in general have a relatively higher acoustic reflection than the crests. The higher reflectivity is likely caused by biogenic reef presence, as these reefs are harder than the surrounding substrate and increase seabed roughness (Manik, 2016). It could also indicate that the sand wave valleys comprise relatively harder substrates than the sand wave crests, which may favour the settlement of $S$. spinulosa. The fisheries data suggests that the extent of the reefs may be negatively impacted by fishing activity, with the greatest reef extent being observed under the lowest fishing pressure. The dominant fishing gears deployed in the area are beam trawlers with a mesh size of 70-99 mm, targeting sole (Solea solea) and plaice (Pleuronectes platessa) (van der Reijden et al., 2014). Their gears consist of two nets towed alongside the vessel with a towing speed of around 6 knots (Rijnsdorp et al., 1998). Each net is $12 \mathrm{~m}$ wide, held open by a solid construction (the beam or a so-called 

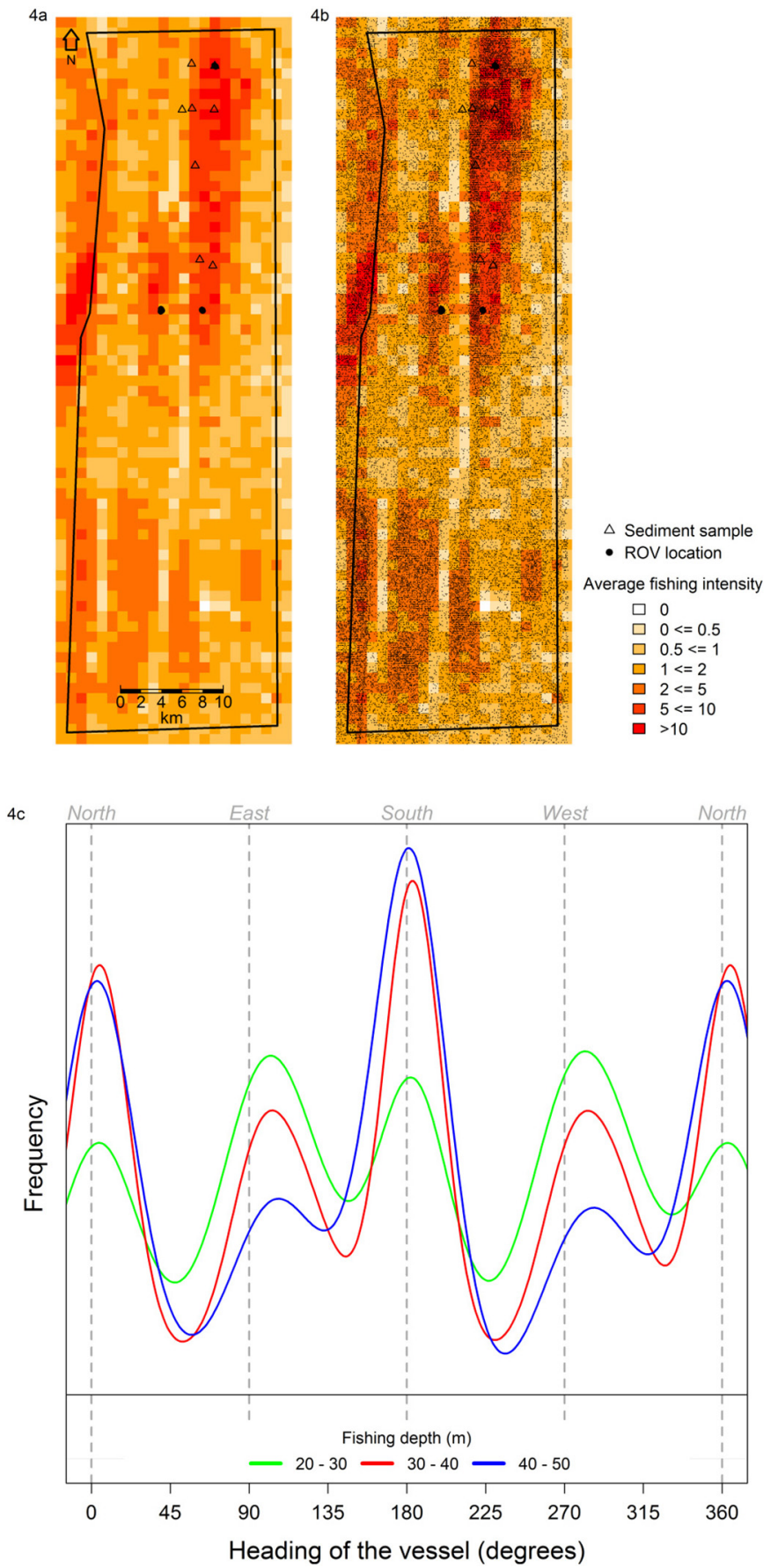

Fig. 4. Overview of fisheries data, showing the average fishing intensity (total yearly swept area $\left(\mathrm{km}^{2}\right)$ per $1 \times 1 \mathrm{~km}$ grid cell) in the Brown Bank area, without (a) and with (b) exact satellite locations of all Dutch demersal fisheries in the period 2008-2015. Sediment sample locations are indicated, as well as the ROV locations. A density plot of the vessels' heading for all fishing VMSpings for the dominant fisheries (beam-trawl with $70-99 \mathrm{~mm}$ mesh size) is given in (c), separated for the active fishing depth classes. (For interpretation of the references to colour in this figure legend, the reader is referred to the web version of this article.)

sumwing), fitted with tickler chains or electrodes stimulating fish to enter the nets (Eigaard et al., 2015; Haasnoot et al., 2014; Poos and Rijnsdorp, 2007; Soetaert et al., 2015). Based on the registered heading of all VMS pings classified as 'fishing', we showed that the majority of the fishing activity in the large-scale sandbank troughs ( $>40 \mathrm{~m}$ water depth) is in a direction perpendicular to the small-scale sand waves (north to south), potentially 'skipping' the sand wave valleys (Fig. 5).

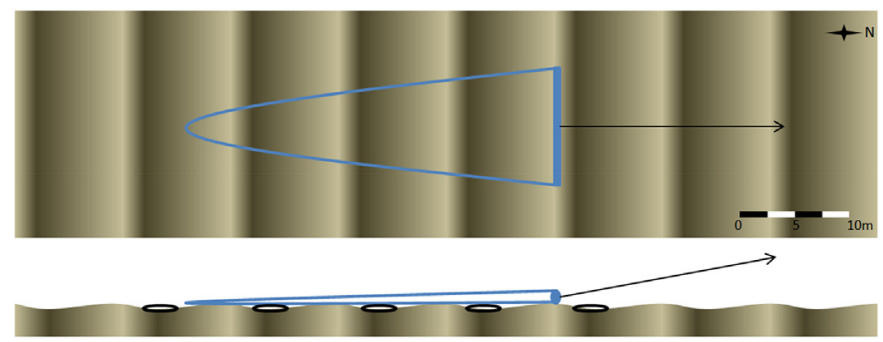

Fig. 5. Sketch of seabed topography in relation to fishing activities, which enables the formation of refuge areas. The top view (a) shows a beam trawl net (blue). The small-scale sand waves (shown by a light top and dark valley) are perpendicular to the main fishing direction. The side view (b) shows a crosssection of the seabed with the sand waves and the potential refuge areas (black ovals). (For interpretation of the references to colour in this figure legend, the reader is referred to the web version of this article.)

Our data show that $S$. spinulosa is not restricted to the created refuge areas. For instance, the most western located reef showed $S$. spinulosa reef both in and outside sand wave valleys. This location also had the lowest fishing intensity, of 1-2 times per year. With higher fishing intensities, the reef was less extensive, and dominantly located within sand wave valleys. These observations suggest that the large-scale sandbank troughs of the Brown Bank area create favourable conditions for $S$. spinulosa reefs, but that the reefs are restricted to refuge areas under high fishing pressures. As $S$. spinulosa larvae prefer to settle on cement secretions of their own species (Wilson, 1970), the persistence of $S$. spinulosa reefs in refuge areas may enable for a fast recovery of fragmented reefs if fishing pressure decreases.

We discovered the described $S$. spinulosa reefs in the Brown Bank area by chance, but it is very likely that more $S$. spinulosa reefs exist in the surrounding area. Accidental discoveries might be made during the obligatory monitoring prior to constructions of wind farms and pipelines and the extraction of marine aggregates (Pearce et al., 2014). However, our data suggests that dedicated surveys should focus on sand bank trough areas with low fishing pressures and an average grain size of $350 \mu \mathrm{m}$. In particular, efforts should be focussed on the small-scale refuge areas located in sand waves valleys, which unfortunately cannot be predicted by fishing intensity maps alone. Areas prohibited for fisheries, like safety zones around oil platforms and offshore wind farms could also form a useful focus for future studies. With remote acoustic scanning methods like side scan sonar, the chosen areas can then easily be scanned for reef-like structures (Pearce et al., 2014). Groundtruthing should be performed to verify $S$. spinulosa presence and reef extent (OSPAR Commission, 2013). This ground-truthing does not necessarily have to be done with expensive ROVs as used here; towed video and drop-down camera systems may give similar results (Hendrick and Foster-Smith, 2006).

S. spinulosa reefs are known to locally increase biodiversity, providing shelter and substrate for other species within their 3D-structure (OSPAR Commission, 2013; Pearce et al., 2014). Our video footage supports this. Reef structures with a height up to $50 \mathrm{~cm}$ were observed, showing species sheltering in between reef fragments. Epifauna species abundance was notably higher within the reefs than in adjacent areas. Some observations within the reefs included species that are known for their association with hard substrates, for example the rock gunnel, the velvet crab, and the edible crab (Hayward and Ryland, 1990; Krone et al., 2013; Shorty and Gannon, 2013). We showed that the longclawed porcelain crab is massively abundant between the tubes of the $S$. spinulosa reefs, which is a very important prey item for many associated fish species (Pearce et al., 2013). Moreover, the small-spotted catshark was observed to rest in between $S$. spinulosa reefs. These observations emphasize the importance of the $S$. spinulosa reefs for the ecosystem, and may also explain why fishermen are very active in the area.

Our discovery of significant $S$. spinulosa reefs on the Dutch 
Continental Shelf could have important implications. Biogenic reefs, including $S$. spinulosa reefs, are classified as natural habitat type "Reefs" (H1170) in Annex I of the Habitat Directive. Moreover, the OSPAR Convention has listed $S$. spinulosa reefs in the Greater North Sea on the OSPAR list of threatened and or declining species and habitats (OSPAR Commission, 2008). As one of the Contracting Parties of the OSPAR Convention, the Netherlands is committed to protect listed species and habitats, including $S$. spinulosa reefs in accordance with Annex V of the OSPAR Convention. As such, the Netherlands have obliged themselves to collect more information about the extent and structure of these reefs, and to ensure sustainable management of human activities based on the ecological requirements of the reefs.

\section{Acknowledgements}

We would like to thank the Dutch Postcode Lottery for their generous funding of the OCEANA project 'Protecting the North Sea 2017: Biodiversity Hotspots and recovering fish stocks'. We are grateful to the crew of both OCEANA and the Neptune for their help in the field. The Dutch ministry of Agriculture, Nature and Food Quality and Wageningen Marine Research are acknowledged for the provisioning of the Dutch VMS-data. We also thank Leendert Dorst and Daniëlle van Kuijk of the Hydrographic Service within the Royal Netherlands Navy for making the high-resolution bathymetry data of the Brown Bank area available to us. K.J. van der Reijden, L. Koop, S. O'Flynn, C. van Sluis, P.M.J. Herman, D. Simons, H. Olff, T. Ysebaert, M. Snellen and L.L. Govers received financial support from the Gieskes-Strijbis fund.

\section{Author contributions}

KR, LK, SOF, SG, DM collected data. KR, LK, SOF and DM analysed the data. KR drafted the first version of the manuscript. All authors contributed significantly to the drafts and gave final approval for publication.

\section{References}

Airoldi, L., Beck, M.W., 2007. Loss, Status and Trends for Coastal Marine Habitats of Europe, Oceanography and Marine Biology: An Annual Review. Oceanography and Marine Biology: An Annual Review. https://doi.org/10.1201/9781420050943.

Alevizos, E., Snellen, M., Simons, D.G., Siemes, K., Greinert, J., 2015. Acoustic discrimination of relatively homogeneous fine sediments using Bayesian classification on MBES data. Mar. Geol. 370, 31-42. https://doi.org/10.1016/j.margeo.2015.10. 007.

Bordehore, C., Ramos-Esplá, A.A., Riosmena-Rodríguez, R., 2003. Comparative study of two maerl beds with different otter trawling history, Southeast Iberian Peninsula. Aquat. Conserv. Mar. Freshwat. Ecosyst. 13, S43-S54. https://doi.org/10.1002/aqc. 567.

Burrough, P.A., McDonnell, R., 1998. Principles of Geographical Information Systems. Oxford University Press.

Coggan, R., Mitchell, A., White, J., Golding, N., 2007. Recommended operating guidelines (ROG) for underwater video and photographic imaging techniques. MESH report VIDEO ROG v11. Source: https://www.researchgate.net/publication/281293781_ Recommended_operating_guidelines_ROG_for_underwater_video_and_photographic_ imaging techniques.

Collins, K., 2003. Dorset Marine Habitat Surveys: Maerl, Worm Reefs, Bream Nests, Sea Fans and Brittlestars.

Connell, J.H., 1978. Diversity in tropical rain forests and coral reefs. Science 80 (199), 1302-1310. https://doi.org/10.1126/science.199.4335.1302.

Donadi, S., van der Heide, T., van der Zee, E.M., Eklöf, J.S., van de Koppel, J., Weerman, E.J., Piersma, T., Olff, H., Eriksson, B.K., 2013. Cross-habitat interactions among bivalve species control community structure on intertidal flats. Ecology 94, 489-498.

Dutch Ministry of Infrastructure and the Environment, 2014. Marine Strategy for the Dutch Part of the North Sea 2012-2020. (Part 2. MSFD Monitoring Programme, summary).

Eigaard, O.R., Bastardie, F., Breen, M., Dinesen, G.E., Hintzen, N.T., Laffargue, P., Mortensen, L.O., Nielsen, J.R., Nilsson, H.C., O'Neill, F.G., Polet, H., Reid, D.G., Sala, A., Sköld, M., Smith, C., Sorensen, T.K., Tully, O., Zengin, M., Rijnsdorp, A.D., 2015. Estimating seabed pressure from demersal trawls, seines, and dredges based on gear design and dimensions. ICES J. Mar. Sci. 73, 27-43. https://doi.org/10.1093/ icesjms/fst176.

Eigaard, O.R., Bastardie, F., Hintzen, N.T., Buhl-Mortensen, L., Buhl-Mortensen, P., Catarino, R., Dinesen, G.E., Fock, H., Geitner, K., Gerritsen, H., Gonzalez, M.M., Jonsson, P., Kavadas, S., Laffargue, P., Lundy, M., Mirelis, G.G., Nielsen, J.R.,
Papadopoulou, N., Posen, P., Pulcinella, J., Russo, T., Sala, A., Silva, C., Smith, C., Vanelslander, B., Zengin, M., Rijnsdorp, A.D., 2017. Benthic impact of fisheries in European waters: the distribution and intensity of bottom trawling. ICES J. Mar. Sci. 74, 847-865. https://doi.org/10.1093/icesjms/fsw194.

Eleftherakis, D., Amiri-Simkooei, A., Snellen, M., Simons, D.G., 2012. Improving riverbed sediment classification using backscatter and depth residual features of multi-beam echo-sounder systems. J. Acoust. Soc. Am. 131, 3710-3725. https://doi.org/10. 1121/1.3699206.

Eleftherakis, D., Snellen, M., Amiri-Simkooei, A., Simons, D.G., Siemes, K., 2014. Observations regarding coarse sediment classification based on multi-beam echosounder's backscatter strength and depth residuals in Dutch rivers. J. Acoust. Soc. Am. 135, 3305-3315. https://doi.org/10.1121/1.4875236.

Ferrario, F., Beck, M.W., Storlazzi, C.D., Micheli, F., Shepard, C.C., Airoldi, L., 2014. The effectiveness of coral reefs for coastal hazard risk reduction and adaptation. Nat. Commun. 5, 3794. https://doi.org/10.1038/ncomms4794.

Gibb, N., Tillin, H., Pearce, B., Tyler-Walters, H., 2014. Assessing the sensitivity of Sabellaria spinulosa reef biotopes to pressures associated with marine activities. JNCC Rep. 504.

Gratwicke, B., Speight, M.R., 2005. The relationship between fish species richness, abundance and habitat complexity in a range of shallow tropical marine habitats. J. Fish Biol. 66, 650-667. https://doi.org/10.1111/j.1095-8649.2005.00629.x.

Gravina, M.F., Cardone, F., Bonifazi, A., Bertrandino, M.S., Chimienti, G., Longo, C., Marzano, C.N., Moretti, M., Lisco, S., Moretti, V., Corriero, G., Giangrande, A., 2018. Sabellaria spinulosa (Polychaeta, Annelida) reefs in the Mediterranean Sea: Habitat mapping, dynamics and associated fauna for conservation management. Estuar. Coast. Shelf Sci. 200, 248-257. https://doi.org/10.1016/j.ecss.2017.11.017.

Haasnoot, T., Kraan, M., Bush, S.R., 2014. Fishing gear transitions: lessons from the Dutch flatfish pulse trawl. ICES J. Mar. Sci. 73, 1235-1243. https://doi.org/10.1093/ icesjms/fst176.

Hayward, P., Ryland, J., 1990. The Marine Fauna of the British Isles and North-West Europe. Clarendon Press, Oxford.

Hendrick, V.J., Foster-Smith, R.L., 2006. Sabellaria spinulosa reef: a scoring system for evaluating 'reefiness' in the context of the Habitats Directive. J. Mar. Biol. Assoc. UK 86, 665-677. https://doi.org/10.1017/S0025315406013555.

Hiddink, J.G., Jennings, S., Sciberras, M., Szostek, C.L., Hughes, K.M., Ellis, N., Rijnsdorp, A.D., McConnaughey, R.A., Mazor, T., Hilborn, R., Collie, J.S., Pitcher, R., Amoroso, R.O., Parma, A.M., Suuronen, P., Kaiser, M.J., 2017. Global analysis of depletion and recovery of seabed biota after bottom trawling disturbance. Proc. Natl. Acad. Sci. 1-6. https://doi.org/10.1073/pnas.1618858114.

Hintzen, N.T., Bastardie, F., Beare, D., Piet, G.J., Ulrich, C., Deporte, N., Egekvist, J., Degel, H., 2012. VMStools: Open-source software for the processing, analysis and visualisation of fisheries logbook and VMS data. Fish. Res. 115-116, 31-43. https:// doi.org/10.1016/j.fishres.2011.11.007.

Hitchin, R., Turner, J.A., Verling, E., 2015. Epibiota Remote Monitoring from Digital Imagery: Operational Guidelines. NMBAQC Scheme report. Source: http://www. nmbaqcs.org/media/1591/epibiota_operational_guidelines_final.pdf (29p).

Hoegh-Guldberg, O., Mumby, P.J., Hooten, A.J., Steneck, R.S., Greenfield, P., Gomez, E., Harvell, C.D., Sale, P.F., Edwards, A.J., Caldeira, K., Knowlton, N., Eakin, C.M., Iglesias-Prieto, R., Muthinga, N., Bradbury, R.H., Dubi, A., Hatziolos, M.E., 2008. Coral reefs under rapic climate change and ocean acidification. Science 80 (318), 1737-1742. https://doi.org/10.1126/science.1152509.

Houziaux, J.-S., Kerckhof, F., Degrendele, K., Roche, M., Norro, A., 2008. The Hinder Banks: Yet an Important Area for the Belgian Marine Biodiversity?.

Jenkins, C., Eggleton, J., Albrecht, J., Barry, J., Duncan, G., Golding, N., O'Connor, J., 2015. North Norfolk Sandbank and Saturn Reef cSAC/SCI Management Investigation Report.

Jones, C.G., Lawton, J.H., Shachak, M., 1994. Organisms as ecosystem engineers. Oikos 69, 373-386.

Jones, L.A., Hiscock, K., Connor, D.W., 2000. Marine Habitat Reviews. A Summary of Ecological Requirements and Sensitivity Characteristics for the Conservation and Management of Marine SACs.

Knaapen, M.A.F., 2009. Sandbank occurrence on the Dutch continental shelf in the North Sea. Geo-Marine Lett. 29, 17-24. https://doi.org/10.1007/s00367-008-0105-7.

Krone, R., Gutow, L., Brey, T., Dannheim, J., Schröder, A., 2013. Mobile demersal megafauna at artificial structures in the German Bight - likely effects of offshore wind farm development. Estuar. Coast. Shelf Sci. 125, 1-9. https://doi.org/10.1016/j.ecss. 2013.03.012.

Lenihan, H.S., 1999. Physical-biological coupling on oyster reefs: how habitat structure influences individual performance. Ecol. Monogr. 69, 251-275.

Limpenny, D.S., Foster-Smith, R.L., Edwards, T.M., Hendrick, V.J., Diesing, M., Eggleton, J.D., Meadows, W.J., Crutchfield, Z., Pfeifer, S., Reach, I.S., 2010. Best methods for identifying and evaluating Sabellaria spinulosa and cobble reef. Aggregate Levy Sustainability Fund Project MAL0008. Peterborough.

Lisco, S., Moretti, M., Moretti, V., Cardone, F., Corriero, G., Longo, C., 2017. Sedimentological features of Sabellaria spinulosa biocontructions. Mar. Pet. Geol. 87, 203-212. https://doi.org/10.1016/j.marpetgeo.2017.06.013.

Manik, H.M., 2016. Acoustical measurement and biot model for coral reef detection and quantification. Adv. Acoust. Vib. https://doi.org/10.1155/2016/2350615.

Marine Information and Data Centre [WWW Document], n.d. URL https://www. informatiehuismarien.nl/uk/opendata/ (accessed 6.29.18).

Nieuwenhuize, J., Maas, Y.E.M., Middelburg, J.J., 1994. Rapid analysis of organic carbon and nitrogen in particulate materials. Mar. Chem. 45, 217-224. https://doi.org/10. 1016/0304-4203(94)90005-1.

Ocean Biogeographic Information System (OBIS) [WWW Document], n.d. URL http:// www.iobis.org/explore/\#/taxon/505197 (accessed 6.29.18)

OSPAR Commission, 2008. Case Reports for the OSPAR List of Threatened and/or 
Declining Species and Habitats.

OSPAR Commission, 2010. Quality Status Report 2010. London.

OSPAR Commission, 2013. Background Document on Sabellaria Spinulosa Reefs.

Pearce, B., 2014. The Ecology of Sabellaria Spinulosa Reefs. University of Plymouth.

Pearce, B., Hill, J.M., Wilson, C., Griffin, R., Earnshaw, S., Pitts, J., 2013. Sabellaria

Spinulosa Reef Ecology and Ecosystem Services. The Crown Estate. https://doi.org/ 10.13140/2.1.4856.0644.

Pearce, B., Fariñas-Franco, J.M., Wilson, C., Pitts, J., Somer, P.J., 2014. Repeated mapping of reefs constructed by Sabellaria spinulosa Leuckart 1849 at an offshore wind farm site. Cont. Shelf Res. 83, 3-13. https://doi.org/10.1016/j.csr.2014.02.003.

Piet, G.J., Hintzen, N.T., 2012. Indicators of fishing pressure and seafloor integrity. ICES J. Mar. Sci. 69, 1850-1858. https://doi.org/10.1093/icesjms/fss162.

Poos, J.J., Rijnsdorp, A.D., 2007. The dynamics of small-scale patchiness of plaice and sole as reflected in the catch rates of the Dutch beam trawl fleet and its implications for the fleet dynamics. J. Sea Res. 58, 100-112. https://doi.org/10.1016/j.seares. 2007.01.006.

Rabaut, M., Vincx, M., Degraer, S., 2009. Do Lanice conchilega (sandmason) aggregations classify as reefs? Quantifying habitat modifying effects. Helgol. Mar. Res. 63, 37-46. https://doi.org/10.1007/s10152-008-0137-4.

Reise, K., 1982. Long-term changes in the macrobenthic invertebrate fauna of the Wadden Sea: are polychaetes about to take over? Neth. J. Sea Res. 16, 29-36. https://doi.org/ 10.1016/0077-7579(82)90014-X.

Reise, K., Schubert, A., 1987. Macrobenthic turnover in the subtidal Wadden Sea: the Norderaue revisited after 60 years. Helgoländer Meeresun. 41, 69-82. https://doi. org/10.1007/BF02365100.

Rijnsdorp, A.D., Buys, A.M., Storbeck, F., Visser, E.G., 1998. Micro-scale distribution of beam trawl effort in the southern North Sea between 1993 and 1996 in relation to the trawling frequency of the sea bed and the impact on benthic organisms. ICES J. Mar. Sci. 55, 403-419. https://doi.org/10.1006/jmsc.1997.0326.

Ryer, C.H., Stoner, A.W., Titgen, R.H., 2004. Behavioral mechanisms underlying the refuge value of benthic habitat structure for two flatfishes with differing anti-predator strategies. Mar. Ecol. Prog. Ser. 268, 231-243. https://doi.org/10.3354/ meps268231.

Shorty, J.T., Gannon, D.P., 2013. Habitat selection by the Rock Gunnel, Pholis gunnellus L. (Pholidae). Northeast. Nat. 20, 155-170.

Simons, D.G., Snellen, M., 2009. A Bayesian approach to seafloor classification using multi-beam echo-sounder backscatter data. Appl. Acoust. 70, 1258-1268. https:// doi.org/10.1016/j.apacoust.2008.07.013.

Snellen, M., Gaida, T.C., Koop, L., Alevizos, E., Simons, D.G., 2018. Performance of multibeam echosounder backscatter-based classification for monitoring sediment distributions using multitemporal large-scale ocean data sets. IEEE J. Oceanic Eng. https://doi.org/10.1109/JOE.2018.2791878.

Soetaert, M., Decostere, A., Polet, H., Verschueren, B., Chiers, K., 2015. Electrotrawling: a promising alternative fishing technique warranting further exploration. Fish Fish. 16, 104-124. https://doi.org/10.1111/faf.12047.

The Marine Life Information Network (MarLIN) [WWW Document], n.d. URL http:// www.marlin.ac.uk/species/detail/1133 (accessed 6.29.18).

The National Biodiversity Network (NBN) Atlas [WWW Document], n.d. URL https:// species.nbnatlas.org/species/NHMSYS0021049244 (accessed 6.29.18).

van Denderen, P.D., Bolam, S.G., Hiddink, J.G., Jennings, S., Kenny, A., Rijnsdorp, A.D., van Kooten, T., 2015. Similar effects of bottom trawling and natural disturbance on composition and function of benthic communities across habitats. Mar. Ecol. Prog. Ser. 541, 31-43. https://doi.org/10.3354/meps11550.

van der Reijden, K.J., Verkempynck, R., Nijman, R.R., Uhlmann, S.S., Van Helmond, A.T.M., Coers, A., 2014. Discard self-sampling of Dutch bottom-trawl and seine fisheries in 2013. CVO Rep. 14, 007.

van der Zee, E.M., van der Heide, T., Donadi, S., Eklöf, J.S., Eriksson, B.K., Olff, H., van der Veer, H.W., Piersma, T., 2012. Spatially extended habitat modification by intertidal reef-building bivalves has implications for consumer-resource interactions. Ecosystems 15, 664-673. https://doi.org/10.1007/s10021-012-9538-y.

van der Zee, E.M., Angelini, C., Govers, L.L., Christianen, M.J.A., Altieri, A.H., van der Reijden, K.J., Silliman, B.R., van de Koppel, J., van der Geest, M., Van Gils, J.A., van de Veer, H.W., Piersma, T., de Ruiter, P.C., Olff, H., van der Heide, T., 2016. How habitat-modifying organisms structure the food web of two coastal ecosystems. Proc. R. Soc. B 283, 20152326. https://doi.org/10.1098/rspb.2015.2326.

van Dijk, T.A.G.P., van Dalfsen, J.A., van Lancker, V., van Overmeeren, R.A., van Heteren, S., Doornenbal, P.J., 2012. Benthic habitat variations over tidal ridges, North Sea, the Netherlands. In: Harris, P.T., Baker, E.K. (Eds.), Seafloor Geomorphology as Benthic Habitat. Elsevier Inc., London, pp. 241-249. https://doi.org/10.1016/B978-0-12385140-6.00013-X.

Vorberg, R., 2000. Effects of shrimp fisheries on reefs of Sabellaria spinulosa (Polychaeta). ICES J. Mar. Sci. 57, 1416-1420. https://doi.org/10.1006/jmsc.2000. 0920.

Wilson, D.P., 1970. The larvae of Sabellaria spinulosa and their settlement behaviour. J. Mar. Biol. Assoc. UK 50, 33-52.

Witbaard, R., Lavaleye, M.S.S., Duineveld, G.C.A., Bergman, M.J.N., 2013. Atlas of the Megabenthos (incl. small fish) on the Dutch Continental Shelf of the North Sea. NIOZ Report 2013-4. 